\title{
Social identity of transgender persons: concept analysis and proposition of nursing diagnoses
}

\author{
Identidade social da pessoa transgênero: análise do conceito e proposição do diagnóstico de enfermagem \\ Identidad social de la persona transgénero: análisis conceptual y propuesta de diagnóstico de enfermería
}

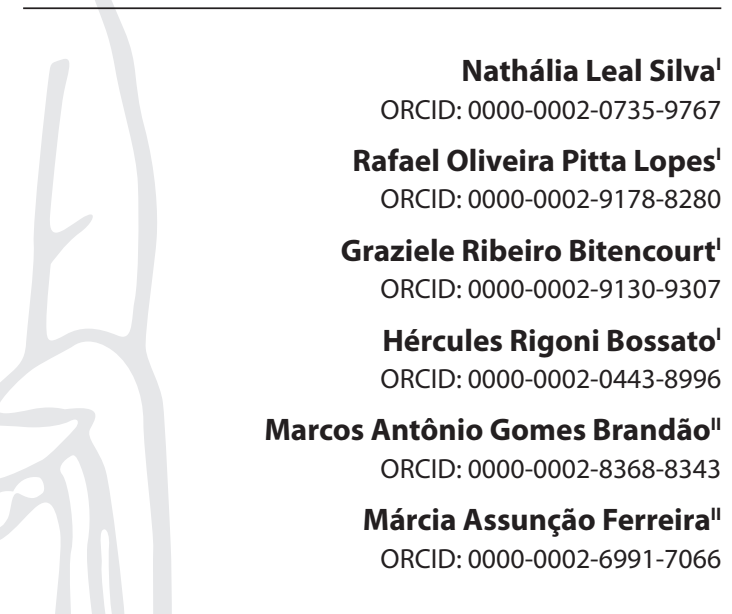

'Universidade Federal do Rio de Janeiro. Macaé, Rio de Janeiro, Brazil.

"Universidade Federal do Rio de Janeiro. Rio de Janeiro, Rio de Janeiro, Brazil.

How to cite this article: Silva NL, Lopes ROP, Bitencourt GR, Bossato HR Brandão MAG, Ferreira MA. Social identity of transgender persons: concept analysis and proposition of nursing diagnosis. Rev Bras Enferm. 2020;73(Suppl 5):e20200070. doi: http://dx.doi.org/10.1590/0034-7167-2020-0070

Corresponding author:

Rafael Oliveira Pitta Lopes E-mail: pitta_rafael@hotmail.com

EDITOR IN CHIEF: Antonio José De Almeida Filho ASSOCIATE EDITOR: Fátima Helena Espírito Santo

Submission: $03-31-2020$

Approval: 07-13-2020

\section{ABSTRACT}

Objective: To analyze the concept of social identity of transgender persons and develop nursing diagnoses related to it. Methods: A concept analysis according to the Walker and Avant model. A scope review was carried out with a search of eight databases, a portal and two information systems, during June and July 2019. Articles, theses, and dissertations were analyzed in Portuguese, English, and Spanish, with no time frame definition. Results: Of the 6.847 productions, 10 were included, and the concept of social identity was described in 4 of them. Critical, prior, and consequential attributes for the social identity of transgender persons were identified, and the analysis of the concept substantiated the proposal of the diagnosis: Willingness to improve the social identity of the transgender person. Conclusion: Social identity establishes a relationship with health, and the proposed nursing diagnosis strengthens the sense of belonging of transgender people, enhancing their rights as citizens. Descriptors: Social Identification; Nursing Diagnosis; Transgender Persons; Health Promotion; Transsexualism; Concept Formation.

\section{RESUMO}

Objetivo: Analisar o conceito de identidade social da pessoa transgênero e elaborar um diagnóstico de enfermagem relacionado à identidade social da pessoa transgênero. Métodos: Análise de conceito segundo modelo de Walker e Avant. Realizou-se uma revisão de escopo com busca em oito bases de dados, um portal e dois sistemas de informação, em junho e julho de 2019. Analisaram-se artigos, teses e dissertações, nos idiomas português, inglês e espanhol, sem recorte temporal. Resultados: Das 6.847 produções, 10 foram incluídas, e o conceito de identidade social foi descrito em 4 delas. Identificaram-se os atributos críticos, antecedentes e consequentes para a identidade social da pessoa transgênero, e a análise do conceito fundamentou a proposição do diagnóstico: Disposição para a identidade social melhorada da pessoa transgênero. Conclusão: A identidade social estabelece relação com a saúde, e diagnóstico de enfermagem proposto fortalece o sentido de pertença das pessoas transgênero, potencializando seus direitos como cidadãos.

Descritores: Identidade Social; Diagnóstico de Enfermagem; Pessoa Transgênero; Promoção da Saúde; Trasnsexualismo; Formação de Conceito.

\section{RESUMEN}

Objetivo: Analizar el concepto de identidad social de la persona transgénero y elaborar un diagnóstico de enfermería relacionado a la identidad social de la persona transgénero. Métodos: Análisis de concepto según modelo de Walker y Avant. Se realizó una revisión de campo con búsqueda en ocho bases de datos, un portal y dos sistemas de información, en junio y julio de 2019. Se analizaron artículos, tesis y disertaciones, en los idiomas portugués, inglés y español, sin recorte temporal. Resultados: De las 6.847 producciones, 10 han sido incluidas, y el concepto de identidad social ha sido descripto en 4 de ellas. Se identificaron los atributos críticos, antecedentes y consecuentes para la identidad social de la persona transgénero, y el análisis del concepto fundamentó la proposición del diagnóstico: Disposición para la identidad social mejorada de la persona transgénero. Conclusión: La identidad social establece relación con la salud, y diagnóstico de enfermería propuesto fortalece el sentido de pertenezca de las personas transgénero, potenciando sus derechos como ciudadanos. Descriptores: Identidad Social; Diagnóstico de Enfermería; Persona Transgénero; Promoción de la Salud; Transexualismo; Formación de Concepto. 


\section{INTRODUCTION}

The term "transgender person" refers to a group of individuals who recognize themselves within socially established gender identities. In addition to the ingrained concepts regarding the identity of men and women, the gender identity that differs from that attributed biologically is decisive, and in this group, transvestites and transsexuals are included ${ }^{(1)}$, are decisive. Thus, the term "trans person" is used to refer to individuals who (self)identify and crosses the different gender categories, producing social behaviors different from those attributed to their biological sex. The breadth of the concept of transgenderism can also encompass the gender identities known as "non-binary", "third gender", and, sometimes, cross-dressing itself. Thus, socially, the binary perspective is overturned, especially in the period of transition of body image and self-concept.

Despite the current social changes, it is still necessary to intensify scientific production and public policies that promote the contact of society with the topic, in order to guarantee a diminution in prejudices and the clarification of issues related to transsexuality. Part of this demand is related to the complex universe of gender formation, which, when considering the variety of sexuality, classifies male and female homosexuals, bisexuals, intersexuals (hermaphrodites), transvestites, and transsexuals, each with their own particularities, with their desires, their physical, emotional, psychically contextualized realities and different social spaces ${ }^{(2)}$.

An individual's social identity can be characterized by the aggregation of their bonds to a social system: for example, the bond to a sexual category, age, race, among others. Therefore, identity allows the subject to be in a social system and to be socially established ${ }^{(3)}$. The social perspective of identity is an object of study for different investigations $s^{(4)}$, producing diverse conceptual definitions, theories and scales. In this field, the Social Identity Theory - SIT ${ }^{(5-6)}$, the Group Identity Scale ${ }^{(7)}$, and the Social Identity Trifactorial Scale $(E T I S)^{(8)}$ are examples. Despite the recognized advance in the production in the area, its various conceptual propositions, definitions, and theories can generate divergences and counterpoints in their application in specific settings and social groups. The application of these concepts, both in social groups and in the trans community, is a fundamental initiative for understanding the social dynamics of this vulnerable group, especially because they understand that the visibility or invisibility of the transgender person damages their identity and self-esteem, causing psychological distress that may lead to psychopathologies such as depression and anxiety, among others ${ }^{(9)}$.

Therefore, understanding the social identity of the transgender person, especially in the field of health, provides interfaces to be discussed for the construction of an appropriate nursing practice for this group. Empirical and conceptual researches provide elements for the construction of knowledge that, together with theoretical and philosophical supports, enables a different look at practice ${ }^{(10)}$.

The focus of nursing should not be only on the problem, but include the redistribution of power and control over individuals, family, and collective health issues, in order to achieve a reduction in the negative impact of social, political, and economic determinants ${ }^{(11)}$. In order for nursing actions to have more quality in the care of trans people, it is necessary to understand the diversity of concepts related to social identity and then apply them. In parallel, in addition to the concept, the formalization of a nursing diagnosis of social identity for this population group leads to proposals for specific care, capable of providing more applicable responses to the situations of trans people, especially in the field of health promotion.

The transgender person still goes through a process of exclusion, violence, and prejudice; they are marginalized and socially excluded ${ }^{(12)}$. This situation keeps them away from health systems, drives them ill, and makes social exchanges difficult. In this context, health promotion actions are demanded and must be carried out in the various settings of the territory, whether in the community, at school, at home, or at the health service itself. For such actions, it is necessary to build and recognize the human responses involved in the processes of living and becoming ill. This will enable the direction and strengthen the development of nursing planning and interventions.

The production and use of nursing diagnosis, especially focused on health promotion, enables the individualized development, planning, and intervention, considering clinical judgments related to health, aimed at seeking healthier behaviors ${ }^{(13)}$.

\section{OBJECTIVE}

To analyze the concept of social identity of the transgender person and propose a nursing diagnostic related to their social identity.

\section{METHODS}

\section{Ethical aspects}

This is a concept analysis study, and thus, it was not submitted for appreciation by the Research Ethics Committee. The studies were identified using alphanumeric codes, with the letter $\mathrm{E}$ followed by a sequential number.

\section{Study design}

Concept analysis study with scope review to obtain elements for a "nursing diagnosis" construct.

\section{Study protocol}

The scope review design was chosen due to the possibility of mapping the main concepts that give support to a given area of knowledge, of examining the extent, scope, and nature of the investigation, summarizing and disseminating the investigation data, in addition to identifying the existing gap ${ }^{(14)}$. The methodological procedures for conducting this review were: definition of the review question; identification of relevant studies; selection of studies; data mapping; and finally, confrontation with other data, summary and reporting the results ${ }^{(15)}$.

To formulate the review question, the acronym PCC was used, which represents: person, concept, and context ${ }^{(15)}$. The study population is composed by transgender people; the concept 
was social identity; and the context was not determined. Thus, the following review question was: "How is the process of social identity of the transgender person described?"

The search strategy applied the following descriptors: "Social identification"; "Self concept"; "Transgender"; "Transgender persons"; "Transsexualism". For the crossing, Boolean operators "AND" and "OR" were used, building the search key: ("Social identification" OR "Self-concept") AND ("transgender" OR "Transgender people" OR "transsexualism"); in English: ("Social identification" OR "Self concept") AND ("transgender"OR"Transgender persons" OR "transsexualism"); in Spanish: ("Identificación social" OR "Autoconcepto") AND ("transgénero" OR "Personas transgénero" OR "transsexualismo"). The following filters were selected: type of resource (article) and language (English, Portuguese and Spanish). The same search key was used in the following databases: ScienceDirect Journals (Elsevier); SpringerLink; PubMed Central (PMC); Taylor \& Francis Online - Journals; Science Citation Index Expanded (Web of Science); MEDLINE \PubMed (NLM); psycINFO - American Psychological Association; CINAHL; Scopus (Elsevier). To capture the gray literature, the OpenGrey, MedNar, Thesis and Dissertation CAPES and DART - Europe Catalog were verified. As gray literature, theses, dissertations, and articles published on unconventional bases were considered. The search stage in the databases took place in the months of June and July 2019, using the reference manager Mendeley 1.19.4. The review was carried out based on the PRISMA methodology - Preferred Reporting Items for Systematic Reviews and Meta-Analyses ${ }^{(16)}$, with no time limit.

The following productions were included: theses, dissertations and original articles with a qualitative and quantitative approach, reflection articles, integrative and systematic reviews that dealt with the social identity of transgender persons, published in any year, in Portuguese, English, and Spanish. Letters to editors and short reviews were excluded. The selection of publications and data extraction were carried out by two people; and, in cases of disagreement, a debate was held between the evaluators, in search for consensus.

\section{Study protocol for concept analysis}

In order to operationalize the concept analysis, the model proposed by Walker and Avant ${ }^{(17)}$ was applied, in view of the necessary mapping of prior events, defining attributes and consequences of the social identity of the transgender person, including the proposal of the nursing diagnostic "Willingness for improving the social identity of transgender persons". Walker and Avant's model ${ }^{(17)}$ is rigorous and systematic, being widely used in literature ${ }^{(18)}$. A concept analysis study is a formal and linguistic exercise that examines the elements of a concept, their use, and how different or similar it is from other related words. It provides more precise definitions for concepts to be used in theories and research. However, since the concepts are dynamic, a concept analysis should never be considered as a finished product, but as a definition of attributes at a specific moment ${ }^{(19)}$.

The process presented the following steps: selection of the concept, determination of the objectives of the analysis, identification of the uses of the concept, determination of the defining attributes, identification of a model case, identification of a contrary case, identification of prior events, and consequences and definition of the empirical references.

In the first stage, for the concept analysis, the concept selected was "social identity of transgender persons". The objective of the concept analysis is to produce the knowledge necessary for proposing a nursing diagnosis of the health promotion type. This method has been considered as a form to conduct the Phase 1 of nursing diagnosis validations ${ }^{(20)}$.

With the analysis, the aim was to evaluate the use of the concept of social identity with regard to its construction process in transgender people. The use of such a concept and the findings about the process made it possible to produce a model case and an opposite case. The analysis process ensured the decoding of the elements of the social identity process of transgender persons into prior, critical, and consequent attributes and empirical references.

In the elaboration of the model case and the opposite case, critical attributes and evidences of non-formation of social identity were used, which, together with the authors' creativity, formed fictitious cases that pragmatically exemplify the analyzed concept and its non-formation. The cases were written considering the SOAP format (Subjective, Objective, Evaluation and Plan/Action).

To identify the prior events, an attempt was made to answer the question: "What events, situations, and phenomena produce, stimulate or precede the formation of the social identity of the transgender person?"In addition, the background that prevents or impairs their formation was also verified. The classification of critical attributes was made by deciding which words, expressions, situations, and phenomena would be used by the authors to describe the essential characteristics of the social identity of the transgender person. The identification of the consequences was guided by the question: "What are the events, situations, and phenomena that result from social identity in transgender people?"The consequences of not forming a social identity were also verified.

\section{Study protocol for the proposition of a diagnosis}

After analyzing the concept of the social identity of the transgender person, an interpretation of the findings and extrapolation to the context of nursing diagnosis of health promotion was conducted. Thus, the critical attributes of the social identity of the transgender person were verified and used as a diagnosis focus for proposing a diagnostic related to the social identity of the transgender person.

\section{RESULTS}

The search found 6,847 works, of which 5,603 articles were found on conventional bases and 1,244 in gray literature (including theses, dissertations, and articles). After the identification of duplicate studies, 5,503 productions were selected. Ten studies were obtained after the application of the steps of the PRISMA methodology and the inclusion and exclusion criteria; they constituted the corpus of the study. The selection process is shown in Figure 1. 


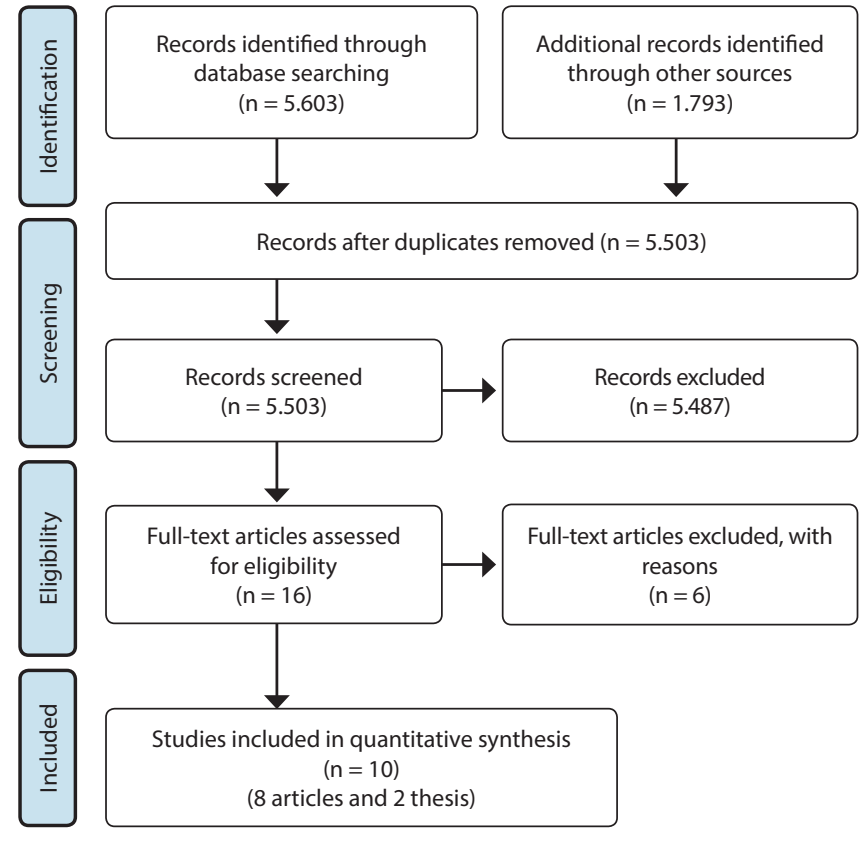

Figure 1 - Flowchart of the article selection process, based on the PRISMA recommendations

The concept of social identity was used and described in four studies (E1, E2, E3, E4). In the other studies, it was found that the social identity of the transgender person was not defined, and others used general definitions of social identity.

The analysis of the concept produced a definition for the social identity of the transgender person, such as the assimilation of characteristics, desires and the establishment of bonds with the group considered to be the identity most solidly established by society, generally that of the opposite gender (external group) to the biological one, associated with the appropriation of characteristics, desires and establishment of a bond with the group that lives the transition process (internal group), generating the emotional and valuable significance of participation within a social system.

To describe and exemplify the social identity of the transgender person, the following model case was produced: P.M.T, 29 years old, trans woman, single. User seeks health service to renew prescriptions for hypertension. She reports that she would like to be identified by her social name, since she recognizes her transgender identity. She expresses a desire to be seen, loved and accepted in all aspects of life, according to the report: "I feel a desire to be seen as a woman, noticed as I see myself and not the way people say I am. I can't wait to find someone who loves me and accepts me. I am not just talking about loving relationships, but in all aspects of my life." Despite expressing the desire to be loved and accepted, she identifies the emotional support she receives from people who experience the same process. The user informs: "Despite all these desires, I found comfort in my 'sisters', who, like me, are going through the same process. With them, I can be freer and more independent because one helps the other, lifts our spirit when everyone else tries to knock it down." The search for autonomy also stands out, as previously reported. Physical examination: oriented in time and space. Normally colored, hydrated, afebrile, acyanotic, and anicteric. Cardiac auscultation: normophonetic sounds in two stages. Pulmonary auscultation: audible breath sounds without adventitious sounds. Flat, peristaltic abdomen and painless on palpation. Upper and lower limbs free from edema. Vesicointestinal functions spontaneously present (AIC). Vital signs: heart rate - 88 beats per minute; respiratory rate - 20 incursions per minute; temperature - 36.9 ${ }^{\circ} \mathrm{C}$; blood pressure $-130 \times 80 \mathrm{mmHg}$. User is in the process of body transformation. Complains of discomfort in the process of altering the tone of voice. In use: Estradiol $\beta 17$ valerate (estradiol valerate) administered via IM, usually used at a dose of 5 to 20 $\mathrm{mg}$, once every two weeks in the unit; hydrochlorothiazide 25 $\mathrm{mg}$ and atenolol $50 \mathrm{mg}$. The blood pressure verification values were evaluated, and the prescription of medication for arterial hypertension was renewed.

In order to exemplify the non-establishment of a social identity of the transgender person, an opposite case was constructed, being:T.M.C, 22 years old, woman, single. User seeks health service because she is feeling sad. She reports feeling invisible and excluded in different social contexts, especially in the labor market. She expresses a desire of not having been born, as she feels that she will never be seen the way she wants to be. According to the user: "Iwould rather not have been born, because it is not normal to be like that; I have tried to have more feminine manners or liking women's things to fit in better, to meet my family's expectations. But I can't, I like shorts, big clothes and a cap. I prefer to hang out with the guys, but they do not want me, because I am a woman. And because I dress like this and act my way, people look at me differently, even health professionals look at me with disdain. I think I am different, new, so I do not make friends and that will never change." In addition, she claims to leave her home little, as it causes her discomfort to be among other people. She indicates that she will never be loved because her body is not the one she wants and she does not feel motivated to adapt her body so that she will not be called a "macho woman". She asks to be called by her name of birth, although she likes the nickname "Boné". During the consultation, she had a crying fit and wanted to leave. She was asked to stay, but she was resistant and left the consultation abruptly.

Based on the studies, the priors of the social identity of the transgender person were classified: social support from members of the trans community (E1, E2, E4, E5); understanding of gender identity itself; gender expression and transition (E3, E6); childhood traits of behaviors traditionally considered of the opposite gender to that of their birth (E3, E4); media (E7); support from friends, family and other contacts of significance to the person (E8); greater family involvement in the transition process (E4, E8). Some priors were determined to prevent or impair the formation of social identity: social messages that minimize or devalue identities (E1, E7, E9); invisibility or exclusion of transgender people from different sociocultural contexts (E9).

The critical attributes for the formation of social identity are: greater proximity to the trans community $(E 7, E 6)$; desire to be or being in process of body transformation (E3, E4, E8, E10); search for autonomy (E6); desire to be perceived, loved and accepted in all aspects of life (E8, E10); recognition as transgender (E5); recognition of the social name $(E 3, E 4)$. 
The consequences of social identity include positive body self-image (E3, E4); comfort with your gender (E2, E6, E9); resistance to negative social messages (E7, E9); strengthening of trans identity (E2, E5, E6); satisfaction with life (E2, E4); strengthening of social relations and resilience (E2, E6, E7); social adjustment (E5); lower levels of depression and anxiety, less suicidal behaviors and positive coping behavior (E8); increased self-esteem and quality of life (E4, E8); increased personal confidence (E4). The following feelings were found as a consequence of not forming a social identity: negative self-perception (E9); sadness and depression (E6, E9); internalized transphobia and vulnerability at the individual level (E10); and passive behavior in sexual relations (E3, E10).

Classes or categories of the phenomenon that can be measured in the real world are considered empirical references of the social identity of the transgender person. Thus, based on critical attributes, it is possible to consider as empirical references: the existence of a social network with members of the trans community; creating links with the group considered to be the most solidly established by society; active participation in fights for the recognition of the rights of the trans community; greater autonomy in the development of individual and social activities; sharing a social aesthetic, such as the use of clothes and accessories that embody the identity of the group; undergoing hormonal and surgical treatments to gradually transform their primary and secondary characteristics into those of the desired gender; the expressed desire to be recognized, loved and accepted in society; and the search for registration or use of the social name.

The analysis of the concept provided remarkable elements for the proposal of the nursing diagnostic "Willingness to improve the social identity of transgender persons", which is defined as "Pattern of desire, motivation or conditions for assimilation of characteristics and establishment of bonds that generate emotional and valuable significance of shared membership within a social system of the transgender person that can be improved". The composition of the diagnosis is shown in Figure 2.

\begin{tabular}{|c|c|}
\hline $\begin{array}{l}\text { Domain } \\
\text { Class }\end{array}$ & $\begin{array}{l}\text { Domain } 6 \text { - Self-perception } \\
\text { Class } 1 \text { - Self-concept }\end{array}$ \\
\hline Titles & $\begin{array}{l}\text { Willingness to improve the social identity of the } \\
\text { transgender person }\end{array}$ \\
\hline Definition & $\begin{array}{l}\text { Pattern of desire, motivation, or conditions for } \\
\text { assimilation of characteristics and establishment of } \\
\text { bonds that generate the emotional and valuable } \\
\text { significance of shared membership within a social } \\
\text { system of the transgender person that can be improved }\end{array}$ \\
\hline $\begin{array}{l}\text { Defining } \\
\text { characteristics }\end{array}$ & $\begin{array}{l}\text { - Expresses recognition of their transgender identity } \\
\text { - Expresses desire for greater proximity to the trans } \\
\text { community } \\
\text { - Expresses desire for body transformation } \\
\text { - Expresses desire for autonomy } \\
\text { - Expresses a desire to be seen, loved, and accepted in all } \\
\text { aspects of life } \\
\text { - Expresses desire for recognition of the social name }\end{array}$ \\
\hline
\end{tabular}

Figure 2 - Nursing diagnosis "Willingness to improve the social identity of transgender persons"

\section{DISCUSSION}

The concept of social identity of the transgender person highlights the existence of two groups: the internal, in which one is inserted, also known as "us", a group that transmits an idea of proximity; whereas the external group would be the one in which they are not inserted, i.e., "them", a distant relationship ${ }^{(21)}$. Thus, it is possible to affirm that the desire to be part of the group that differs from the biological designation leads to the perception of a lack of both belonging and social recognition, characterizing this group, initially, as "external". However, once the gender identity is built and recognized, this group is no longer understood as external and becomes internal, coexisting with a group of people who recognize their gender differently from the one biologically designated and live or desire the transition process.

The transgender person identifies and recognizes himself in a shared way in the constructed gender group, as well as in the group of people who perceive themselves and experience the same gender establishment process that differs them from the sex biologically assigned to them ${ }^{(21)}$. In addition, with health procedures and the peculiarities of the transition process, people share their own characteristics with those who experience this process, strengthening the identity of the group that was initially considered internal.

In the field of the legal right to life and health, the different areas of knowledge must be attentive to social movements for the production of epistemological advances. New recognitions have been evidenced in policies for the inclusion of sexual and gender diversity in educational institutions and public and private organizations, as well as in the cultural industry ${ }^{(22)}$. A notable example is the production of the National Policy for the Integral Health of Lesbians, Gays, Bisexuals, Transvestites and Transsexuals (LGBT) in Brazil, recognized as a historic landmark for the visibility of the demands of this population living in conditions of vulnerability ${ }^{(23)}$.

The continuous and complex changes in scientific knowledge and social movements over time reinforce and emphasize the need to develop an analysis of concepts of interest for daily nursing practice. This is important to map and understand new knowledge, produce and redefine concepts of a specific nature of activity and the scientific methodology of the profession ${ }^{(24)}$. In this context, such a strategy has been considered to develop nursing diagnosis, since the clarification of concepts and phenomena provides a basis for nurses to be able to diagnose, plan and effectively intervene ${ }^{(18)}$.

The development of the diagnosis of "Willingness for improving the social identity of transgender persons" as a product of epistemological advancement in nursing stands out, since it is relevant to identify human responses typologically characterized as conclusions of health promotion, especially for vulnerable groups, as nurses take responsibility for identifying health promotion opportunities for individuals, families, groups, and communities. Thus, although the NANDA-I taxonomy offers a domain called "health promotion", it is necessary and desirable to produce and relate diagnosis from other domains to include health promotion actions aimed at different populations ${ }^{(22)}$.

Social identities should be emphasized in the field of health, since the feeling of trans people of belonging to the society of 
which they are part causes integration and leads to the exercise of universal rights and duties, provided for by law ${ }^{(23)}$. Identifying that such a phenomenon produces the assimilation of characteristics, desires, and the establishment of bonds, generating emotional and evaluative significance of subsidized membership within a social system, instrumentalizes actions aimed at health promotion.

The evidence recovered in this study indicates the need for collective actions to promote or maintain the social support for members of the trans community ${ }^{(21,25-27)}$; the role of the media ${ }^{(28)}$; the support of friends, family, and other contacts of significance to the person ${ }^{(27)}$; and greater family involvement in the transition process $^{(27)}$, since these are factors that precede the formation of a social identity for the transgender person.

The benefits of the formation of the identity were also identified by the studies found, with emphasis on: positive body selfimage $^{(26,29)}$; social adjustment ${ }^{(30)}$; comfort with your gender ${ }^{(29,31-32) \text {; }}$ resistance to negative social messages ${ }^{(28,32)}$; strengthening of trans identity ${ }^{(25,27,31)}$; satisfaction with life ${ }^{(25-26)}$; strengthening of social relations and resilience ${ }^{(25,28,31)}$; lower levels of depression and anxiety, less suicidal behavior and positive coping behavior ${ }^{(29)}$; increased self-esteem and quality of life ${ }^{(29,31)}$; and increased personal confidence ${ }^{(26)}$. Therefore, the direct implications of social identity for health are numerous and multifaceted.

Social identity gives people the possibility of recognizing themselves, to know who they are, to know where they belong, to relate and interact in society, in addition to being a way to identify situations of prejudice and discrimination ${ }^{(33)}$. Thus, knowing the elements that give support to the social identity of trans people is part of the set of knowledge necessary to understand human beings, to provide them a better care.

In addition to this, the diagnosis proposition can ensure the identification of an opportunity for health promotion during nursing care, aiming at the consolidation of social identity due to its benefits and for the exercise of care for the transgender person $^{(13)}$. The recognition of this human response is in line with the responsibility of nursing professionals to assume care, not only in a political dimension, but also in an ethical and legal one. In addition, it is important to promote, in educational institutions and scientific associations, debates in favor of technical, scientific, cultural and political development, in favor of sexual and gender minorities ${ }^{(34)}$.

\section{Study limitations}

A variety of possibilities for self-reference were recognized with regard to gender identity; in this context, as a limitation, the proposed diagnostic focuses on a comprehensive social identity for transgender people, without properly addressing the specificities of subgroups that may exist in this population.
Furthermore, the need for clinical and content validation of the nursing diagnosis proposed is necessary.

\section{Contributions to the area of Nursing, Health, or Public Policy}

The proposal of the diagnostic "Willingness to improve the social identity of transgender persons" contributes not only to the consolidation of nursing classification systems, but also to a care proposal that favors the promotion of citizenship, inclusion, and social justice. In this context, it also contributes to potentiate the results of the National LGBT Health Policy, based on the application of a concept of social identity and a nursing diagnostic that enables the provision of appropriate care to the specific situations undergone by the LGBT population.

\section{CONCLUSION}

Social identities enable people to recognize themselves in relation to a certain group, giving them points of reference to establish social relationships and interactions. Thus, social identities have a close relationship with health, since it is understood as a biopsychosocial complex. Nursing diagnosis favor a proposition of care focused on specificities of human responses; meanwhile, the proposition of the diagnosis"Willingness to improve the social identity of transgender persons" contributes for trans people to strengthen their sense of belonging in groups and in the social world and, with this, strengthen themselves before the other social groups, by asserting themselves as citizens with rights.

\section{ERRATUM}

Article"Social identity of transgender persons: concept analysis and proposition of nursing diagnoses", with number of DOI: https://doi.org/10.1590/0034-71672020-0070, published in the journal Revista Brasileira de Enfermagem, 73(Suppl 5):e20200070, on the first page:

Where to read:

Graziele Ribeiro Bitencourt'

ORCID: 0000-0002-9130-9370

Read:

Graziele Ribeiro Bitencourt'

ORCID: 0000-0002-9130-9307

\section{REFERENCES}

1. Silva GWS, Souza EFL, Sena RCF, Moura IBL, Sobreira MVS, Miranda FAN. Cases of violence involving transvestites and transsexuals in a northeastern Brazilian city. Rev Gaúcha Enferm. 2016;37(2):e56407. doi: 10.1590/1983-1447.2016.02.56407

2. Ferreira JA, Tenório SMS, Monteiro TC. Identidade de Gênero: Sobre o Apoio, Identidade e Suporte Social de Travestis, Transexuais e Transgêneros. Psicologado. Edição 05. 2019. Available from: https://psicologado.com.br/psicologia-geral/sexualidade/ identidade-de-genero-sobre-o-apoio-identidade-e-suporte-social-de-travestis-transexuais-e-transgeneros 
3. Berlatto O. A construção da identidade social. Rev Curso Dir FSG[Internet]. 2009 [cited 2019 Oct 20];3(5):141-151. Available from: http://ojs. fsg.br/index.php/direito/article/view/242

4. Nascimento TG. Escala Trifatorial da Identidade Social (ETIS): evidências de sua Adequação Psicométrica. Psico-USF. 2017;22(2):217-34. doi: 10.1590/1413-82712017220203

5. Tajfel H, Turner JC. Differentiation between social groups: studies in the social psychology of intergroup relations. New York: academic. 1978.

6. Tajfel H, Turner JC. An integrative theory of intergroup conflict: the social psychology of intergroup relations. Monterey, Brooks. 1979.

7. Brown R, Condor S, Mathews A, Wade G, Williams J. Explaining intergroup differentiation in an industrial organization. J Occup Psychol. 1986;59(4):279-304. doi: 10.1111/ j.2044-8325.1986.tb00230.x

8. Cameron JE. A three-factor model of social identity: self and identity. 2004;3(3):239-262. doi:10.1080/13576500444000047.

9. Rosa DF, Carvalho MVF, Pereira NR, Rocha NT, Neves VR, Rosa AS. Nursing Care for the transgender population: genders from the perspective of professional practice. Rev Bras Enferm. 2019;72(Suppl 1):299-306. doi: 10.1590/0034-7167-2017-0644

10. Janini JP, Santos RS, Santos LFM, Souza VM. The epistemological construction of transsexuality: the science, nursing and common sense. Esc Anna Nery. 2019;23(3):e20180345. doi: 10.1590/2177-9465-EAN-2018-0345

11. Santos WLD, Nakatani AYK, Santana RF, Bachion MM. Diagnósticos de enfermagem identificados na alta hospitalar de idosos. Cogitare Enferm. 2009;14(2):304-10. doi: 10.5380/ce.v14i2.15622

12. Monteiro S, Brigeiro M, Barbosa RM. Transgender health and rights. Cad Saúde Pública. 2019;35(4):e00047119. doi: $10.1590 / 0102-311 \times 00047119$

13. Monteiro FPM, Araujo TL, Costa FBC, Leandro TA, Cavalcante TF, Lopes MVO. Clinical validation of nursing diagnosis "Willingness for improved infant development". Rev Bras. Enferm. 2016;69(5):855-863. doi: 10.1590/0034-7167-2015-0131

14. Menezes SSCD, Corrêa CG, Silva RDCG, Cruz DDAML. Clinical reasoning in undergraduate nursing education: a scoping review. Rev EsC Enferm USP. 2015;49(6):1032-9. doi: 10.1590/S0080-623420150000600021

15. Peters MDJ, Godfrey C, McInerney P, Soares CB, Khalil H, Parker D. Chapter. Scoping Reviews. In: Aromataris E, Munn Z (Editors). Joanna Briggs Institute Reviewer's Manual [Internet]. The Joanna Briggs Institute, 2017[cited 2019 Sep 15]. Available from https://reviewersmanual.joannabriggs.org.

16. Liberati A, Altman DG, Tetzlaff J, Mulrow C, Gotzsche P, loannidis JPA, et al. The PRISMA statement for reporting systematic reviews and meta-analyses of studies that evaluate health care interventions: explanation and elaboration. PLoS Med. 2009;6(7):e1000100. doi: 10.1371/ journal.pmed. 1000100

17. Walker LO, Avant KC. Strategies for theory construction in nursing. 4th ed. Upper Saddle River: Pearson Prentice Hall; 2005.

18. Anaker A, Elf M. Sustainability in nursing: a concept analysis. Scand J Caring Sci. 2014;28(2):381-389. doi: 10.1111 / scs.12121.

19. Brandão MAG, Mercês CAMF, Lopes RP, Martins JSA, Souza PA, Primo CC. Concept analysis strategies for the development of middle-range nursing theories. Texto context - enferm. 2019;28:e20180390. doi: 10.1590/1980-265x-tce-2018-0390

20. Lopes MVO, Silva VM. Métodos avançados de validação de diagnósticos de enfermagem. In: NANDA International Inc.; Herdman TH, organizador. PRONANDA: programa de atualização em diagnósticos de enfermagem - conceitos básicos. Porto Alegre: Artmed. 2016. pp87-132.

21. Reimer NK. Can intergroup contact foster more continuous, fluid, and inclusive social identities? [Thesis] [Internet] University of Oxford. 2018[cited 2019 Sep 15]. Available from: https://ethos.bl.uk/OrderDetails.do?uin=uk.bl.ethos.770762

22. Maciel-Diniz C, Lima-Ferreira G, Cavalcante-Martins M. Nursing diagnoses associated with the national policy for health promotion. Invest Educ Enferm. 2017;35(1):78-85. doi: 10.17533/udea.iee.v35n1a09

23. Silva BB, Cerqueira-Santos E. Apoio e suporte social na identidade social de travestis, transexuais e transgêneros. Rev SPAGESP [Internet]. 2014 [cited 2019 Sep 15];15(2):27-44. Available from: http://pepsic.bvsalud.org/pdf/rspagesp/v15n2/v15n2a04.pdf

24. Fernandes MGM, Nóbrega MML, Garcia TR, Macêdo-Costa KNF. Análise conceitual: considerações metodológicas. Rev Bras Enferm. 2011;64(6):1150-6. doi: 10.1590/S0034-71672011000600024.25

25. Barr S, Budge S, Adelson J. Transgender community belongingness as a mediator between strength of transgender identity and well-being. J Couns Psychol. 2016;63(1):87-97. doi: 10.1037/cou0000127

26. Silva BB, Santos, EC. Identidade social e autoestima de travestis, homens e mulheres trans. e transgêneros: a influência do apoio social [Dissertação] [Internet]. Universidade Federal de Sergipe - UFS. 2016[cited 2019 Sep 15]. Available from: https://ri.ufs.br/bitstream/ riufs/6034/1/BRUNO_BRITO_SILVA.pdf

27. Davey A, Bouman WP, Arcelus J, Meyer C. Social support and psychological well-being in gender dysphoria: a comparison of patients with matched controls. J Sex Med. 2014;11(12):2976-85. doi: 10.1111/jsm.12681

28. Levitt HM, Ippolito, MR. Being Transgender: The experience of transgender identity development. J Homosex. 2014;61(12):1727-58. doi: 10.1080/00918369.2014.951262

29. Garcia MRV. Identity as a 'patchwork': aspects of identity among low-income Brazilian travestis. Cult Health Sex. 2009;11(6):611-23. doi: 10.1080/13691050902825282

30. Pollock L, Eyre SL. Growth into manhood: identity development among female-to-male transgender youth. Cult Health Sex. 2012; 14:2,20922. doi:10.1080/13691058.2011.636072 
31. Mullen G, Moane G. A qualitative exploration of transgender identity affirmation at the personal, interpersonal, and sociocultural levels. Int J Transgend. 2013;14(3):140-54. doi: 10.1080/15532739.2013.824847

32. Rood B, Reisner S, Puckett J, Surace F, Berman A, Pantalone D. Internalized transphobia: exploring perceptions of social messages in transgender and gender-nonconforming adults. Int J Transgend. 2017;18(4):411-26. doi: 10.1080/15532739.2017.1329048

33. Fernandes SCS, Pereira ME. Endogrupo versus Exogrupo: o papel da identidade social nas relações intergrupais. Estud Pesqui: Psicol. 2018;18(1):30-49. doi: 10.12957/epp.2018.38108

34. Santos JS, Silva RN, Ferreira MA. Health of the LGBTI+ Population in Primary Health Care and the Insertion of Nursing. Esc Anna Nery. 2019;23(4):e20190162. doi: 10.1590/2177-9465-ean-2019-0162 